\title{
MAGELLANIC PENGUIN (SPHENISCIDAE) MONITORING RESULTS FOR MAGDALENA ISLAND (CHILE) 2000 - 2008
}

\author{
RESULTADOS DE LOS ESTUDIOS DE PINGÜINOS DE MAGALLANES (SPHENISCIDAE) \\ EN ISLA MAGDALENA (CHILE) 2000 - 2008
}

Mike Bingham ${ }^{1} \&$ Thora M. Herrmann ${ }^{2}$

\begin{abstract}
Magellanic penguins (Spheniscus magellanicus) are only found around southern South America, with breeding populations in Chile, Argentina and the Falkland Islands (Malvinas). One of Chile's largest and most important Magellanic penguin breeding sites is situated on Magdalena Island in the Straits of Magellan. The island has been designated a national nature reserve because of its importance as a penguin breeding site, and the reserve is managed by the government agency Corporación Nacional Forestal. The island is a popular tourist destination, and Magellanic penguins are increasingly exposed to human activities.

In order to protect this seabird and to ensure the sustainable use of the reserve as a tourist resource, Magdalena Island has been part of a long-term monitoring programme since 1998. This programme does annual census, monitors annual changes in population, breeding success, chick and egg survival rates, and quantifies the effects on human visitation on the behaviour and breeding of penguins. In this paper, we present, analyse and discuss the results of the long-term monitoring 2000-2008.
\end{abstract}

Key words: Monitoring, Magellanic penguin, Spheniscus magellanicus, population dynamics, breeding success, chick and egg survival, disturbance, human presence, bird conservation.

\section{RESUMEN}

Los pingüinos de Magallanes (Spheniscus magellanicus) se encuentran sólo en Sudamérica, con poblaciones reproductivas en Chile, Argentina y las islas Malvinas (Falkland Is.). Uno de los sitios de cría de pingüinos de Magallanes más grande de Chile está situado en la isla Magdalena, en el estrecho de Magallanes. La isla ha sido designada como monumento natural por su importancia como sitio de cría de pingüinos; y es administrada por la Corporación Nacional Forestal. La isla es un popular destino turístico,

\footnotetext{
Organization for the Conservation of Penguins, Casilla 263, Punta Arenas, Chile

2 Canada Research Chair in Biodiversity Conservation and Ethnoecology, Department of Geography, Université de Montréal, Canada, thora. martina.herrmann@umontreal.ca
} 
y el pingüino de Magallanes está expuesto a las crecientes actividades humanas. Para poder proteger esta ave marina y para poder asegurar el uso sustentable de este monumento natural como recurso turístico, se estableció en la isla Magdalena un programa de monitoreo de pingüinos a largo plazo desde 1998. Dentro de este programa se realizan censos anuales de población, se monitorea el éxito reproductivo, tasas de sobrevivencia de huevos y polluelos, se cuantifican los efectos de las visitas y molestias humanas en el comportamiento y la reproducción de la especie. En este artículo presentamos los resultados del monitoreo a largo-plazo efectuado entre 2000 y 2008.

Palabras clave: monitoreo, pingüino de Magallanes, Spheniscus magellanicus, dinámica de población, éxito reproductivo, sobrevivencia de huevos y pichones, disturbio, presencia humana, conservación de aves.

\section{INTRODUCTION}

Magellanic penguins (Spheniscus magellanicus) are only found around southern South America, with breeding populations in Chile, Argentina and the Falkland Islands (Malvinas) ${ }^{1}$. Best guess estimates put the current world population of Magellanic penguins at around 1.5 million breeding pairs, with approximately 700,000 pairs in Chile, 650,000 pairs in Argentina and 150,000 pairs in the Falkland Islands (Bingham 1998, Bingham \& Mejias 1999, Gandini et al. 1998).

Population studies have revealed a 90\% decline in Magellanic penguin populations in the Falkland Islands since the establishment of a commercial fishing industry in 1988 (Bingham 2002). This makes populations in Chile and Argentina even more important, with Magdalena Island being the largest known Magellanic penguin colony in Chile.

Magdalena Island lies in the Straits of Magellan, approximately 32 kilometres north east of the city of Punta Arenas (Fig 1).

Magdalena Island and nearby Marta Island were declared a protected area and named Monumento Natural Los Pingüinos in 1982 because of Magdalena's importance as a Magellanic penguin breeding site. These two islands are now managed by the government agency Corporación Nacional Forestal (CONAF). Magdalena Island is a popular tourist destination, and since 1998 it has been permanently managed by CONAF Park

\footnotetext{
Bertea, L. \& Herrmann, Th.M. (forthcoming) El Pingüino de Magallanes: Colonias del Estrecho de Magallanes - Magellanic penguins: Colonies in the Strait of Magellan - Der Magellanpinguin: Kolonien in der Magellanstra_e - Le manchot de Magellan: Les colonies du détroit de Magellan. Editorial Patagonia Interactiva, Chile, 120 pp.
}

Wardens, who protect the island and assist with tourists who now visit the island by the thousand each summer.

In order to protect and ensure the sustainable use of the reserve as a tourist resource, Magdalena Island has been part of a long-term monitoring programme since 1998 . This programme monitors annual changes in population, breeding success, chick and egg survival rates, and the effects of tourism, allowing the island to be managed for the benefit of both tourists and penguins alike.

\section{MATERIALS AND METHODS}

\section{Population Census}

Because Magellanic penguins live below ground in burrows, and over such a large area, direct nest counts are not possible. Many burrows are unoccupied, and to assume that all burrows contain nests would greatly over-estimate the population size. It was therefore necessary to establish long-term study plots, in which to measure annual nest density.

Seven such plots were established in 2000, six plots of 50 metres by 50 metres and one plot of 30 metres by 100 metres (Fig. 2). This gives a total study area of $18,000 \mathrm{~m}^{2}$ which is approximately $3 \%$ of the total penguin breeding area on Magdalena Island. Every single burrow within these plots is examined in late October to determine the number of occupied nests, and this is used to determine the annual breeding density in nests per square metre. The nesting area is also mapped out using GPS, and multiplying the breeding area of the island in square metres, by the average number of nests per square metre, gives an estimate of the island's po- 


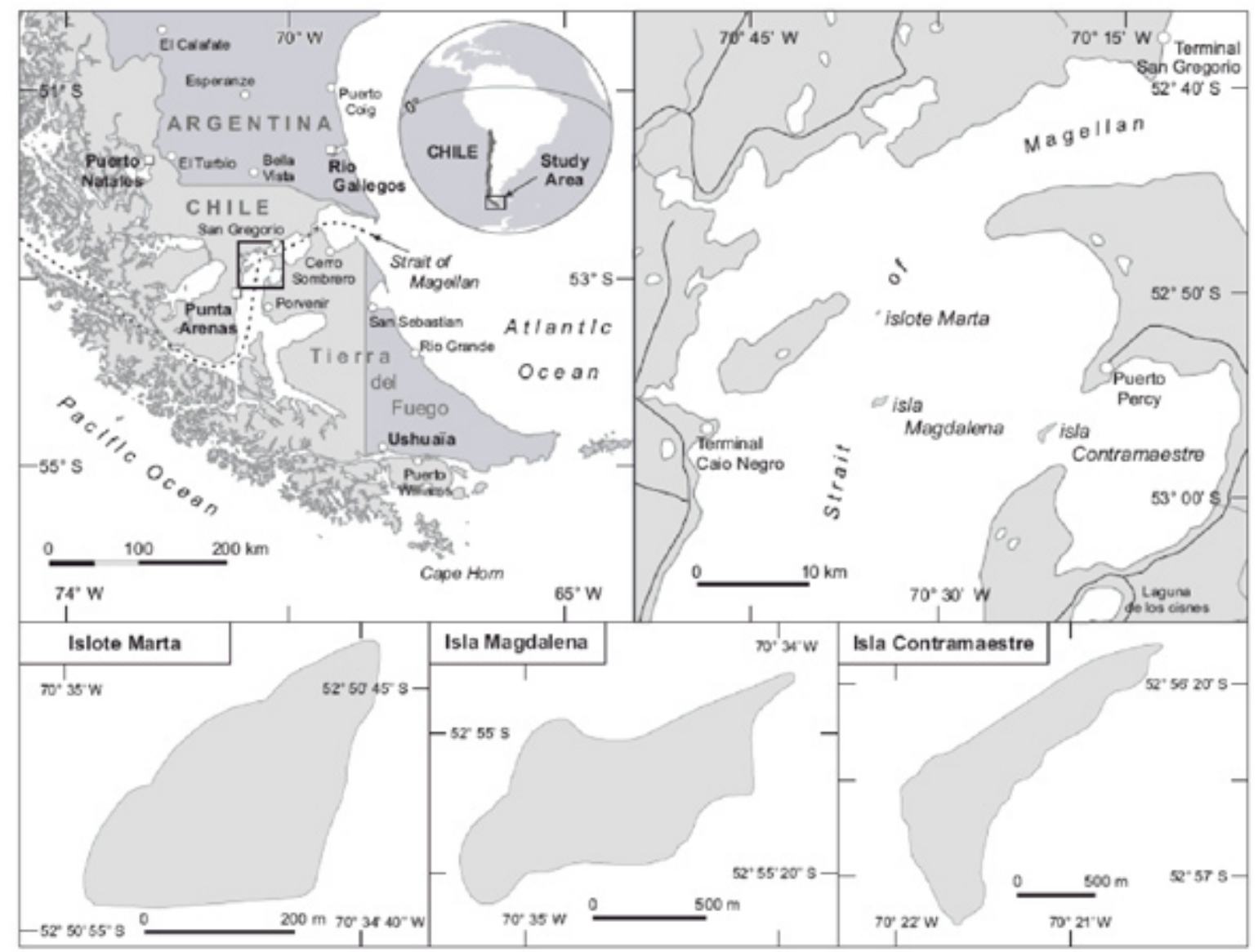

Fig 1: Location of Magdalena Island, Marta Island and Contramaestre Island Cartography: (C) Marc Girard \&Thora Martina Herrmann, Department of Geography, Université de Montréal, Canada, 2008

pulation size (Bingham 2004)2. A similar study was also carried out for nearby Contramaestre Island in November 2002.

The greatest margin for error in determining population size using this method is in the assumption that breeding density recorded in the plots is representative of the entire island, but by using permanent study plots year after year, this margin for error is eliminated when looking for changes in population size. Even minor changes in breeding density, and hence population size and trends, can be measured with great accuracy using permanent study plots, even though a greater margin of error is implied when extending this to defining an actual population size in any particular year.

2 Bingham, M. 2004. Seabird Monitoring Instruction Manual for Magdalena Island. Organization for the Conservation of Penguins, $22 \mathrm{pp}$.

\section{Breeding and Behavioural Analysis}

In addition to studying population changes, in late October, shortly after egg-laying, around 20 occupied nests in each plot are marked, and these nests are visited regularly throughout the season, to determine what proportion of eggs hatch, how many chicks survive to leave the nest, the major causes of egg and chick loss, and chick weight. In addition to the seven study plots, occupied nests alongside the tourist path are also marked and studied, to look for differences in breeding success and chick survival rates resulting from the presence of large numbers of tourists.

During the 2007-2008 seasons, we quantified the behavioural responses and nest abandonment frequency of penguins visited by humans. Methods follow those used by Yorio et al. (1992) and Cevasco 


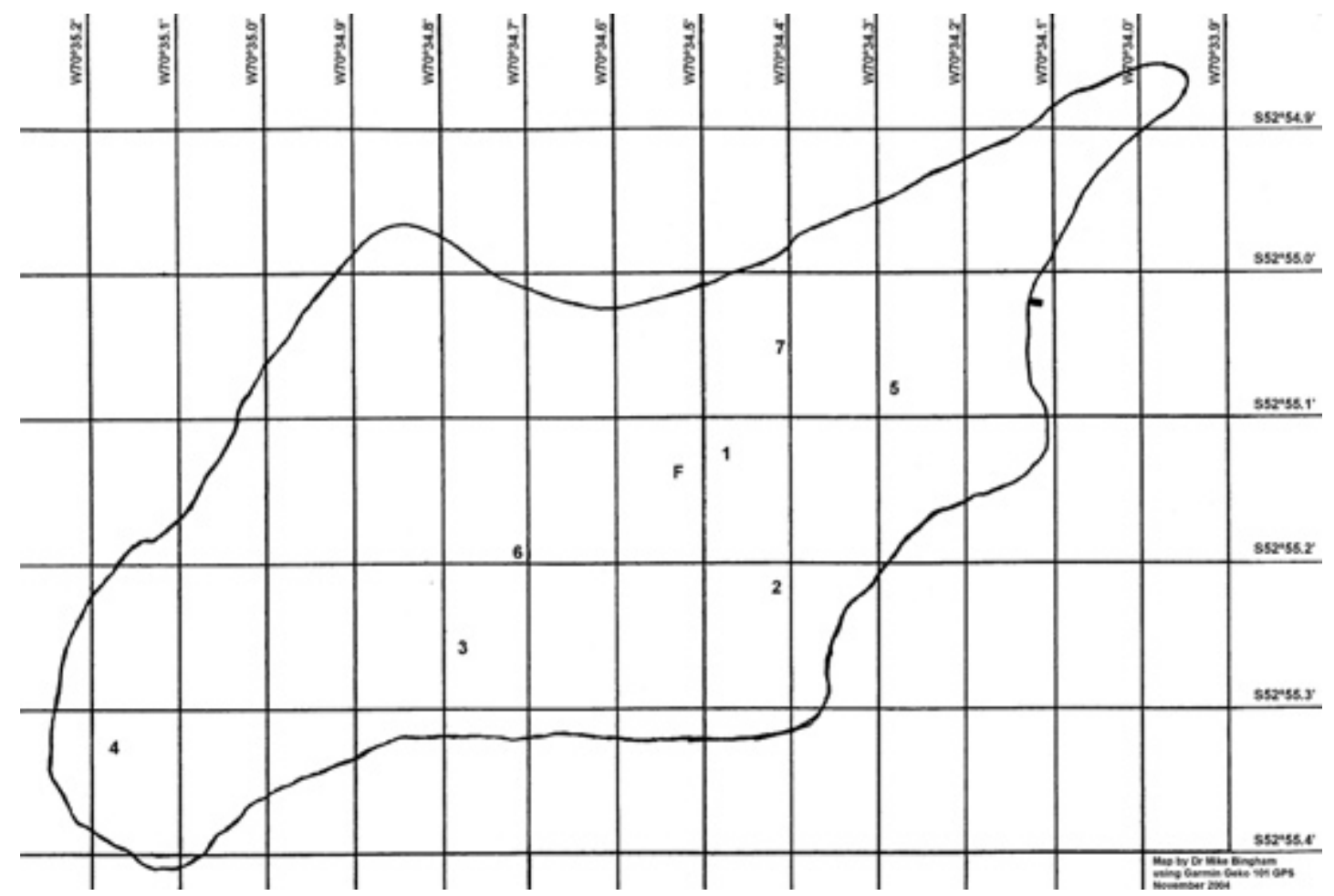

Fig. 2. Location of the study plots on Magdalena Island used for the penguin monitoring Cartography: (c) Mike Bingham, Organization for the Conservation of Penguins, 2004

et al. (2001). The study was carried out in three different areas of the colony: (1) on the tourist trail, (2) in the tourist area, (3) in undisturbed areas far away from tourists. The first area is a fenced area, where tourists walk on a designated trail among the nests; breeding birds can be approached by tourists and on occasion are touched by them. Tourists visit the reserve daily from mid September to late March. Visitors arrive by zodiac in small groups up to 25 people, or by ferry in larger groups of up to 120 people, or in very large groups with up to 600 people (ocean liners usually would book 10 tour buses with 50 passengers each to go on two ferries). The areas not exposed to tourists are located far away from the tourist trail in the interior of the island.

We established two study plots $10 \times 10 \mathrm{~m}$ (P10; P11) in the areas not visited by tourists. In the tourist areas, we established three transects (T1; T2; T3) each containing three study plots (T1=P1,P2,P3; $\mathrm{T} 2=\mathrm{P} 4, \mathrm{P} 5, \mathrm{P} 6$; T3=P7,P8,P9) at 5m, 25m and 50m from the tourist trail. The transects were established in areas with low, middle and high nesting density (Fig. 3).
We quantified the behavioural responses of penguins by walking directly but slowly towards the nest ("approaches") from 25 m away to within $0.5 \mathrm{~m}$. When a penguin changed its behaviour, we noted the distance from the nest and for 10 seconds watched the penguin's behaviour and coded its response. Behaviour categories used were: (1) indifference (when penguin did not show any reaction at all), (b) alert (when penguin turned its head to face the approaching person), (c) alternate stare (when penguin rotated its head alternately and irregularly from side to side but sometimes held briefly on one side), (d) high alert (when penguin rotated its head alternately and irregularly from side to side and gave alarm calls (e) standing up (penguins were lying in nest before they were approached), (f) abandonment (penguin left its burrow when approached).

These approaches were made in each of the five areas during incubation (24-28 October), hatching (25 - 26 November), chick stage (21-23 December), and moulting of the chicks (31 December - 03 January). 


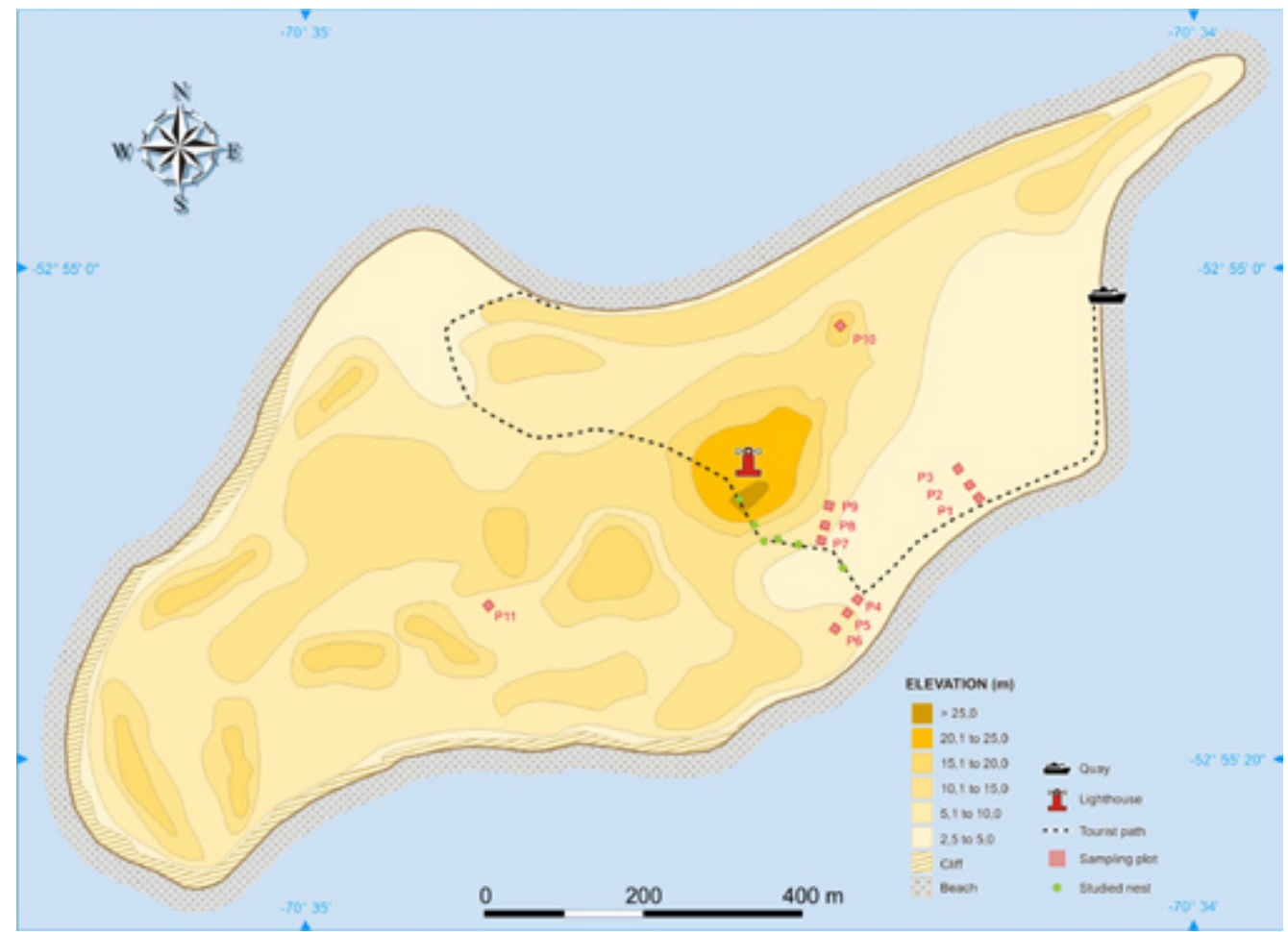

Fig. 3. Location of the study plots on Magdalena Island used for the study on human disturbance on penguin behaviour Cartography: (c) Marc Girard \&Thora Martina Hermann, Department of Geography, Université de Montréal, Canada, 2008

\section{RESULTS AND DISCUSSION}

A baseline survey of Magdalena Island was carried out in 2001, recording the terrain and associated flora and fauna, using methodology specified in Hiscock (1993) ${ }^{3}$ and Bingham (2004). This allows any future changes in the vegetation, and fauna other than penguins, to be assessed at any time in the future, by carrying out a repeat survey. The results of this baseline survey are shown in figures 4 to 7 .

A similar survey of adjacent Contramaestre Island was conducted in 2002 (Figs. 8, 9 and 10).

Penguin population census results show annual fluctuations in population size, but with an overall increase of around 6\% between 2000 (59,000 breeding pairs, Fig. 11) and 2007 (63,000 breeding pairs, Fig. 12). In reality this increase may be greater than studies have shown, since the census of adjacent Contramaestre Island in November 2002 showed a population of nearly 25,000 breeding pairs (Fig.

\footnotetext{
Hiscock, K. 1993. A manual for marine biological inventory surveys.
} Joint Nature Conservation Committee. Report MNCR/OR/19
10), when previous accounts had suggested that just a few years prior the population had been just a few hundred. However a repeat census of Contramaestre Island is required before population trends there can be confirmed.

The breeding distribution map for Magdalena Island (Fig. 12) shows that very few parts of the island are without penguins, and those that are without penguin nests are areas less suitable for nesting. It is therefore reasonable to assume that there is a limit to how much increase in population is possible on Magdalena Island, and that nearby Contramaestre Island has been colonised by penguins from Magdalena. The two islands therefore need to be considered together as one penguin population, and in doing so it is evident that the colony is healthy and expanding.

Studies of marked nests each year support the evidence of a healthy population. Breeding success over the last 8 years (2000 to 2007) has averaged 1.1 chicks per nest (Table 1 ), which is higher than most other Magellanic penguin colonies (Figures 13 to 19). Chick weights at the point of fledging 


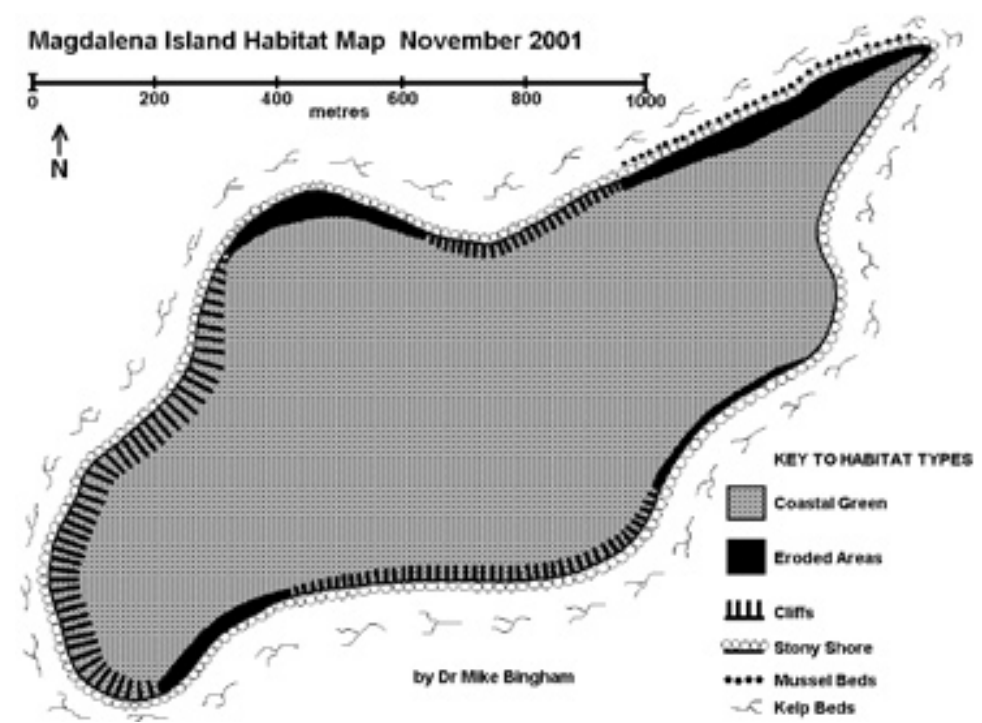

Fig. 4 Magdalena Island habitat map - November 2001

Cartography: (c) Mike Bingham, Organization for the Conservation of Penguins, 2001

have also averaged over 3.3 kilograms, which is higher than most other Magellanic penguin colonies, indicating that chicks are well fed and healthy. Chicks with such high body fat reserves have the best chance possible of surviving as juveniles after leaving the colony.

Comparison of nests alongside the tourist path, with nests in the study plots which are away from tourists (Table 1), shows a slightly higher breeding success for nests close to tourists (near to tourists
$=1.17$ chicks per nest / not near tourists $=1.10$ chicks per nest). With only eight years of data, such a small difference may not be statistically significant, or it may be that predators of the penguin's eggs and chicks, principally skuas, tend to stay away from tourists, reducing the amount of predation on penguin nests near to the tourist path. What is apparent is that these penguins readily adapt to the presence of tourists, and are comfortable with the current level of tourism on Magdalena. Comparing the weight

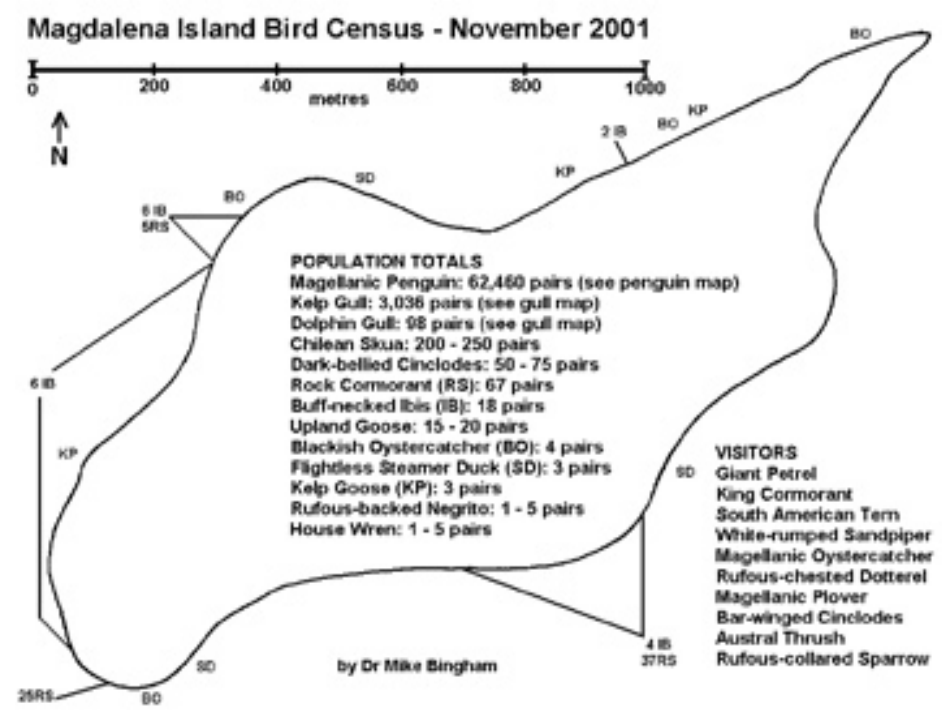

Fig. 5. Magdalena Island bird census - November 2001

Cartography: (c) Mike Bingham, Organization for the Conservation of Penguins, 2001 


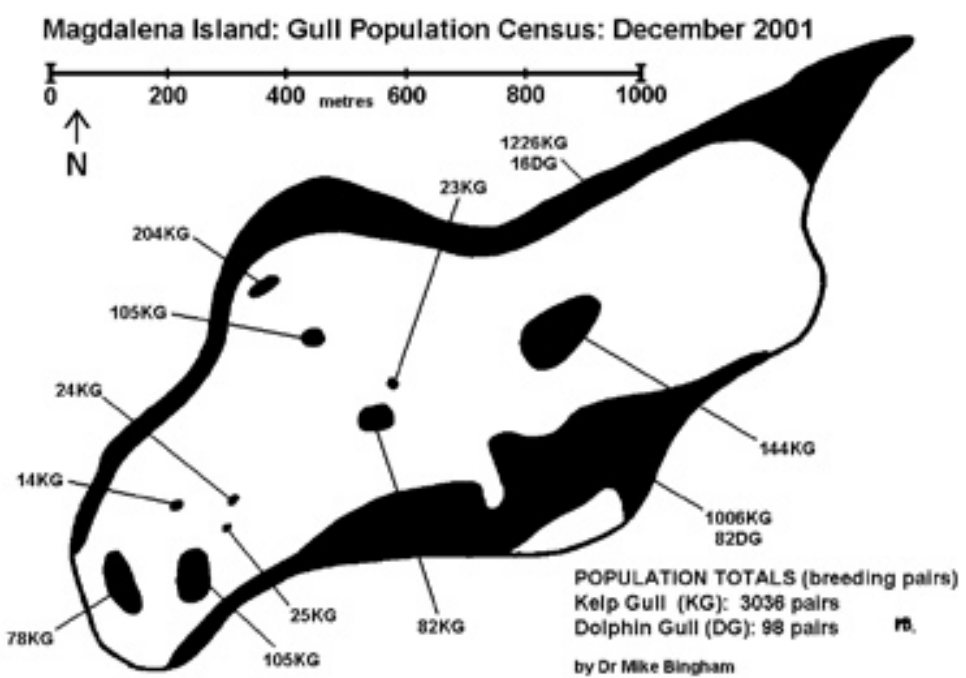

Fig.6. Magdalena Island Gull population census: December 2001

Cartography: (C) Mike Bingham, Organization for the Conservation of Penguins, 2001

at fledging between the chicks raised within the tourist area and those raised in areas not visited by tourists, our data over a six year period (2002 to 2008) show tourist path chicks to be slightly heavier (average weight over six years $=3.34 \mathrm{~kg}$ ) than non tourist areas chicks (average weight over six years $=3.31 \mathrm{~kg})$, although the difference is so small that it is not statistically proven (cf. Table 1).

With respect to the effect of human disturbance on the behavioural pattern of penguins, our study indicated that Magellanic penguins show a differential behavioural response according to their exposure to people. Magellanic penguins on the tourist trail and in the tourist area allowed a closer approach to their burrows before responding than birds nesting in undisturbed areas where tourists do not visit. Some penguins nesting close by the tourist trail were almost indifferent to people approaching them to within $0.5 \mathrm{~m}$, and remained resting with their eyes closed after seeing the visitor. Rarely penguins

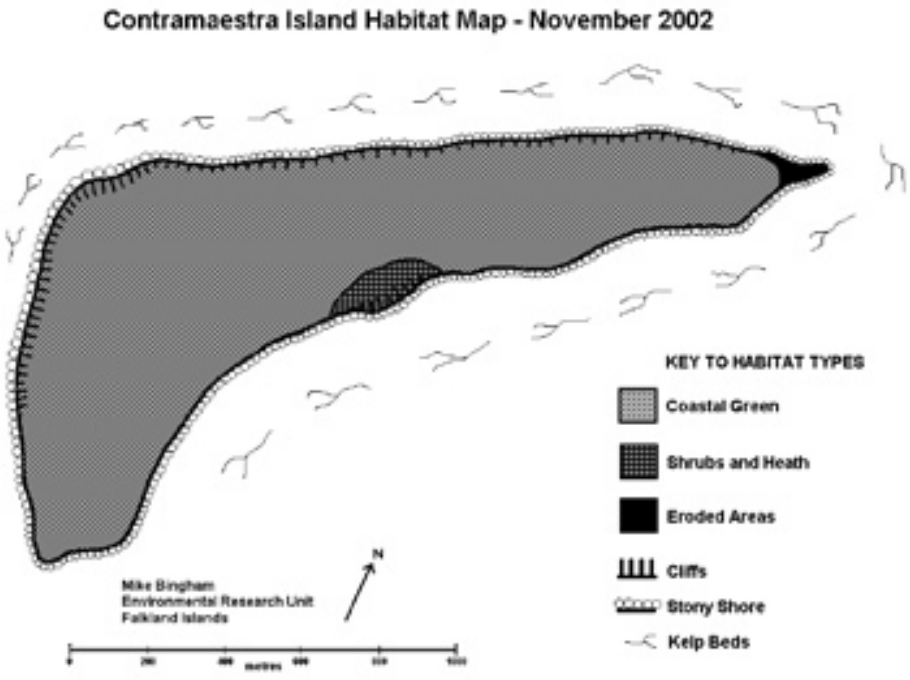

Fig. 7. Magdalena Island: Magellanic penguin distribution - November 2001 Cartography: (C) Mike Bingham, Organization for the Conservation of Penguins, 2001 


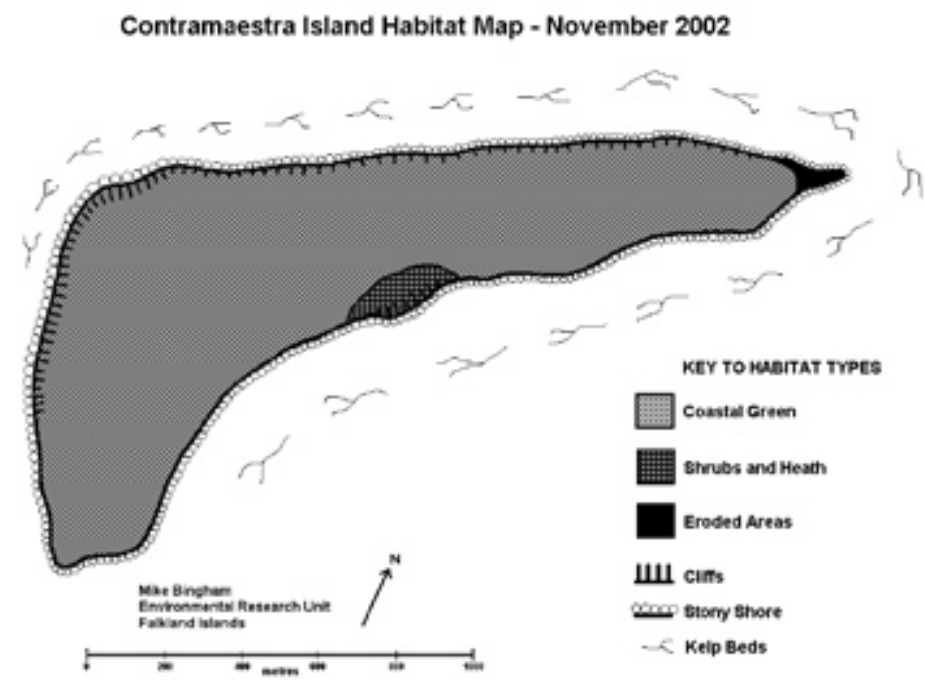

Fig. 8. Contramaestre Island habitat map - November 2002

Cartography: (C) Mike Bingham, Organization for the Conservation of Penguins, 2002

fled their burrows in close human presence (distance $<2 \mathrm{~m}$ ). Only when many penguins were gathered together did they flee when being approached, which is probably due to the high level of group stress. In addition to group stress, another factor of relevance in their flight response is that the birds are not protecting nests. Even single birds not on nests will run, whilst penguins on nests (including open nests) generally do not. In contrast to the tourist areas, penguins nesting in undisturbed areas responded at a greater distance and with more pronounced behaviour. Penguins fled their burrows at a distance of $25 \mathrm{~m}$, or moved very nervously within the nest site; penguin alarm calls signalled the presence of an intruder at $>30 \mathrm{~m}$ distance. These behavioural patterns suggest that penguins that are not used to people are more stressed by occasional visitors.

In essence, penguins breeding in the tourist areas showed a significantly weaker behavioural response to approach than penguins nesting in

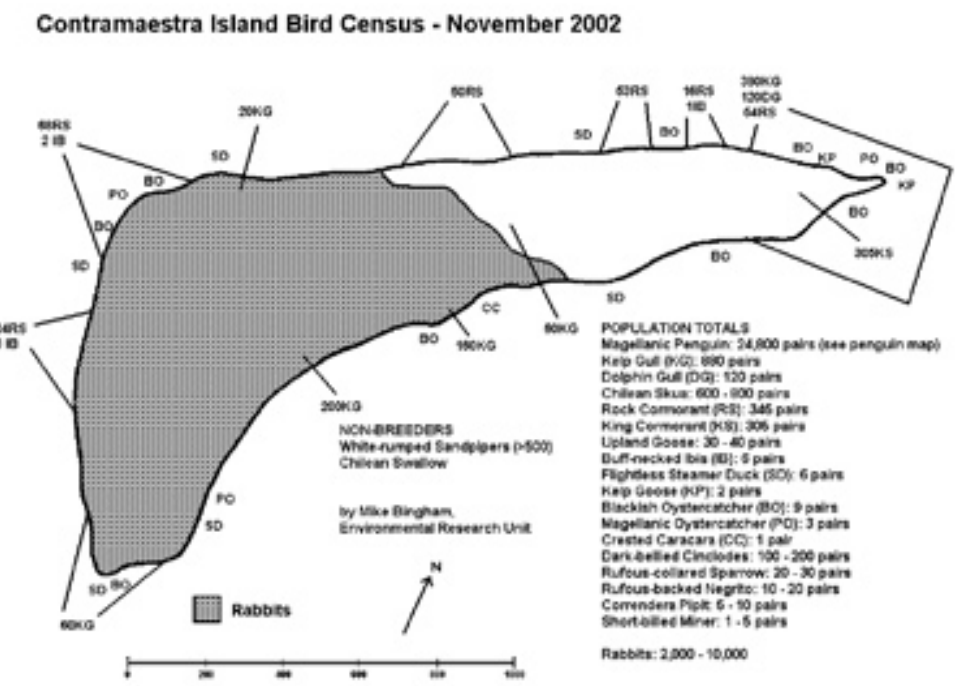

Fig. 9. Contramaestre Island bird census - November 2002

Cartography: (C) Mike Bingham, Organization for the Conservation of Penguins, 2002 


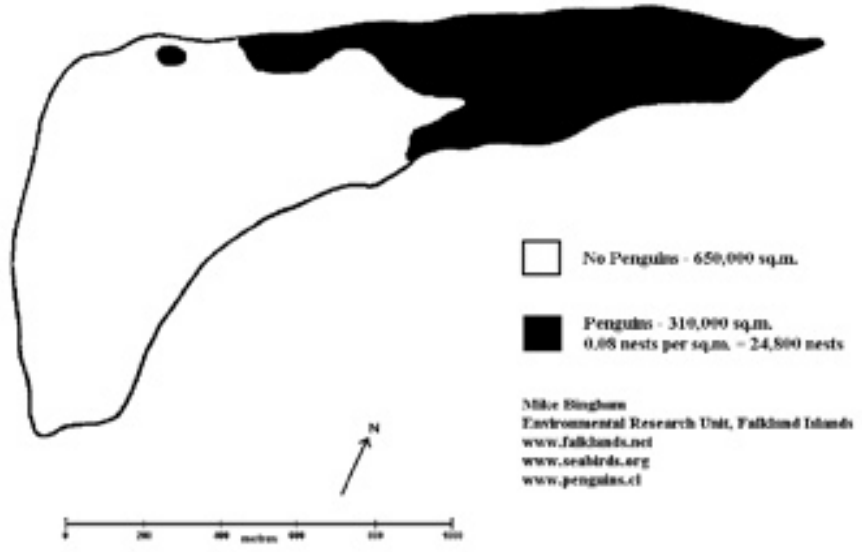

Fig. 10. Contramaestre Island - Magellanic penguin distribution - November 2002 Cartography: (C) Mike Bingham, Organization for the Conservation of Penguins, 2002

undisturbed areas. The variation observed in the behavioural response of Magellanic penguins according to the amount of human disturbance is similar to observations made in other Magellanic penguin colonies in Patagonia (Yorio et al. 1998, Cevasco et al. 2001) and among other penguin species, e.g. Jackass penguins in South Africa (van Heezik \& Seddon 1990).

Annual monitoring of breeding success did reveal one area of concern for the future of penguins on Magdalena Island. During the 2002/03 season, breeding success was very low indeed, averaging just 0.42 chicks per nest, which would be insufficient to maintain the population if such conditions persisted (Fig.14). During the summer of 2001/02 virtually no rain fell on Magdalena Island, and as a result most of the grass on the island died. As a result by the 2002/03 season the island had lost most of its vegetation and was mostly covered in bare earth. The strong winds which always prevail in this area

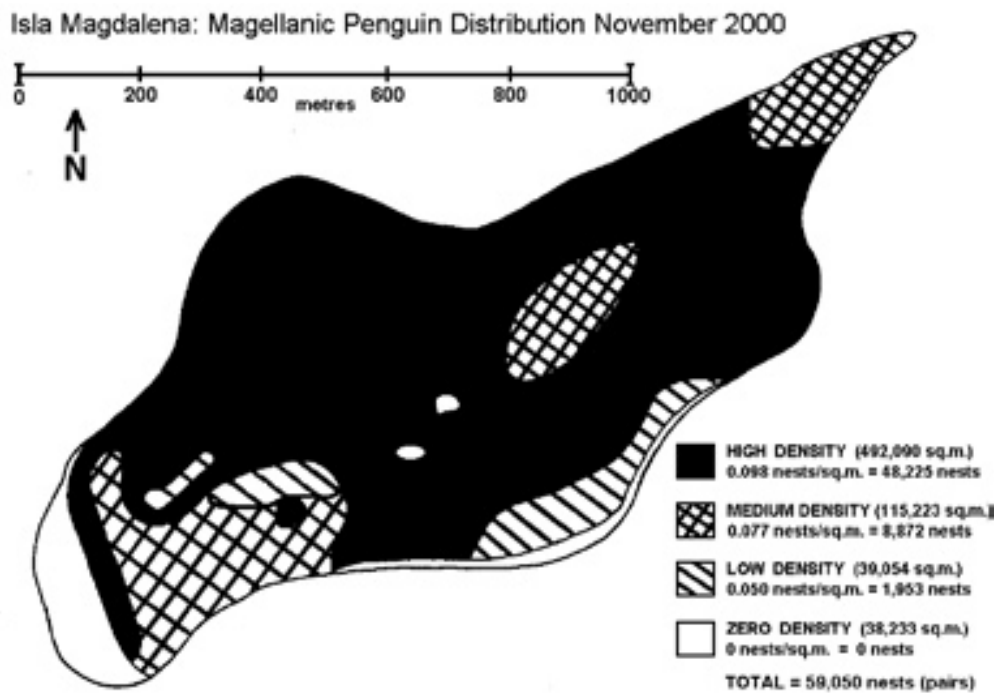

Fig. 11. Magdalena Island - Magellanic penguin distribution - November 2000 Cartography: (C) Mike Bingham, Organization for the Conservation of Penguins, 2000 


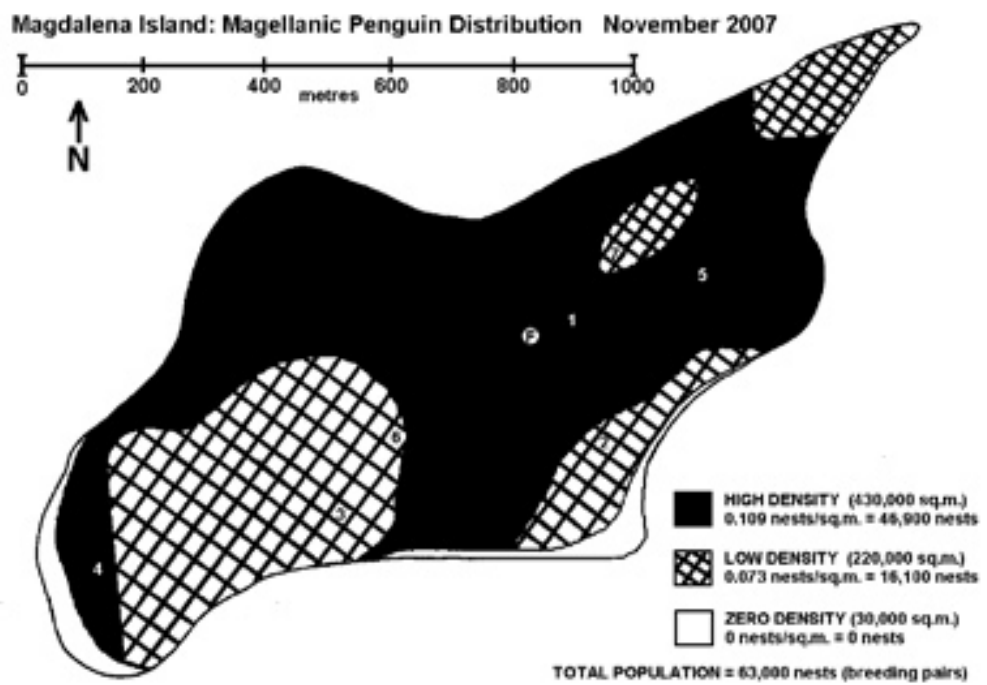

Fig. 12. Magdalena Island - Magellanic penguin distribution - November 2007

Cartography: (C) Mike Bingham, Organization for the Conservation of Penguins, 2007

TABLE 1: Breeding success over the last 8 years (2000 to 2007)

Data source: (C) Mike Bingham, Organization for the Conservation of Penguins,

\begin{tabular}{|c|c|c|c|c|c|c|c|c|}
\hline & Nests & Eggs & Lost as Eggs & Lost Hatching & Lost as chicks & Fledged & $\begin{array}{l}\text { Breeding } \\
\text { Success }\end{array}$ & $\begin{array}{l}\text { Chick } \\
\text { Wt (kg) }\end{array}$ \\
\hline & Nidos & Huevos & Huevos Perdidos & $\begin{array}{l}\text { Eclosión } \\
\text { Perdida }\end{array}$ & $\begin{array}{l}\text { Pichones } \\
\text { Perdidos }\end{array}$ & $\begin{array}{l}\text { Dejaron } \\
\text { el Nido }\end{array}$ & \begin{tabular}{|c|} 
Exito \\
Reproducti-vo \\
\end{tabular} & Peso $(\mathrm{kg})$ \\
\hline $\begin{array}{l}\text { PLOT/ } \\
\text { PARCELA }\end{array}$ & & & & & & & $\begin{array}{l}\text { (pichones } \\
\text { por nido) }\end{array}$ & \\
\hline $2000 / 01$ & 124 & 248 & $23 \%$ & $3 \%$ & $16 \%$ & $58 \%$ & 1.16 & - \\
\hline $2001 / 02$ & 132 & 264 & $10 \%$ & $6 \%$ & $15 \%$ & $69 \%$ & 1.38 & - \\
\hline $2002 / 03$ & 162 & 324 & $63 \%$ & $8 \%$ & $8 \%$ & $21 \%$ & 0.42 & 3.54 \\
\hline $2003 / 04$ & 160 & 320 & $29 \%$ & $5 \%$ & $21 \%$ & $44 \%$ & 0.88 & 3.53 \\
\hline $2004 / 05$ & 130 & 260 & $16 \%$ & $8 \%$ & $10 \%$ & $66 \%$ & 1.32 & 3.19 \\
\hline $2005 / 06$ & 90 & 180 & $34 \%$ & $7 \%$ & $8 \%$ & $51 \%$ & 1.02 & 3.07 \\
\hline $2006 / 07$ & 83 & 166 & $20 \%$ & $4 \%$ & $7 \%$ & $69 \%$ & 1.38 & 3.39 \\
\hline $2007 / 08$ & 90 & 180 & $26 \%$ & $3 \%$ & $8 \%$ & $63 \%$ & 1.26 & 3.16 \\
\hline \multicolumn{9}{|l|}{$\begin{array}{l}\text { PATH/ } \\
\text { SENDERO }\end{array}$} \\
\hline $2000 / 01$ & 35 & 70 & $21 \%$ & $3 \%$ & $15 \%$ & $61 \%$ & 1.22 & - \\
\hline $2001 / 02$ & 19 & 38 & $5 \%$ & $3 \%$ & $19 \%$ & $73 \%$ & 1.46 & - \\
\hline $2002 / 03$ & 37 & 74 & $74 \%$ & $9 \%$ & $7 \%$ & $10 \%$ & 0.20 & 3.58 \\
\hline $2003 / 04$ & 35 & 70 & $28 \%$ & $6 \%$ & $19 \%$ & $47 \%$ & 0.94 & 3.73 \\
\hline $2004 / 05$ & 20 & 40 & $20 \%$ & $5 \%$ & $15 \%$ & $60 \%$ & 1.20 & 3.20 \\
\hline $2005 / 06$ & 31 & 62 & $13 \%$ & $2 \%$ & $3 \%$ & $82 \%$ & 1.64 & 3.18 \\
\hline $2006 / 07$ & 28 & 56 & $21 \%$ & $2 \%$ & $4 \%$ & $73 \%$ & 1.46 & 3.15 \\
\hline $2007 / 08$ & 20 & 40 & $22 \%$ & $3 \%$ & $10 \%$ & $65 \%$ & 1.30 & 3.20 \\
\hline \multicolumn{9}{|l|}{$\begin{array}{l}\text { OPEN/ } \\
\text { ABIERTO }\end{array}$} \\
\hline $2001 / 02$ & 15 & 30 & $17 \%$ & $10 \%$ & $20 \%$ & $53 \%$ & 1.06 & - \\
\hline
\end{tabular}




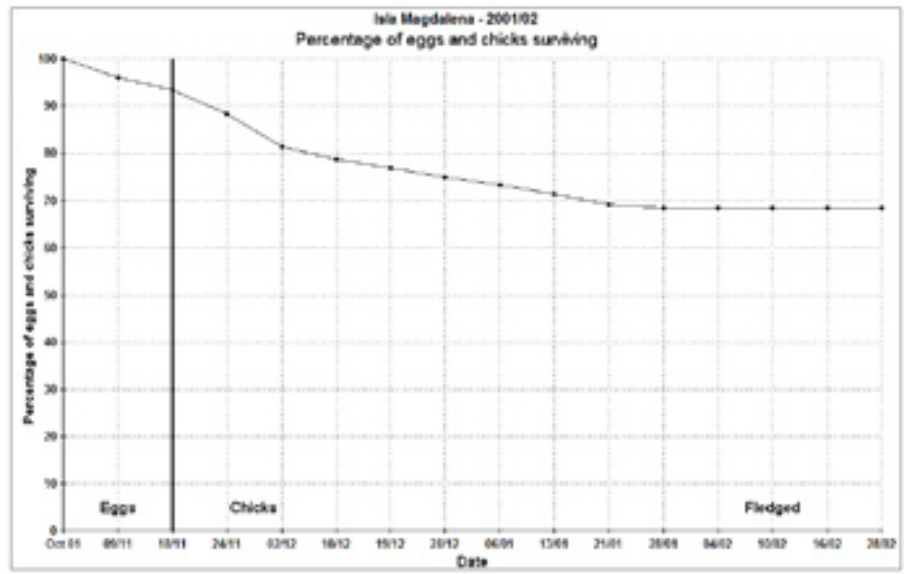

Fig. 13. Percentage of eggs and chicks surviving, Isla Magdalena 2001/02 Data source: (C) Mike Bingham, Organization for the Conservation of Penguins, 2002

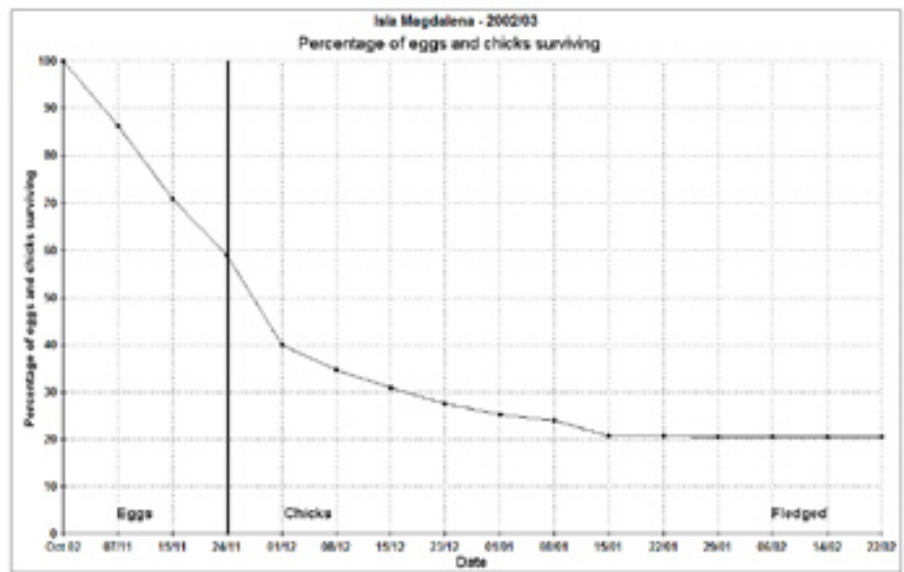

Fig. 14. Percentage of eggs and chicks surviving, Isla Magdalena 2002/03 Data source: (C) Mike Bingham, Organization for the Conservation of Penguins, 2003

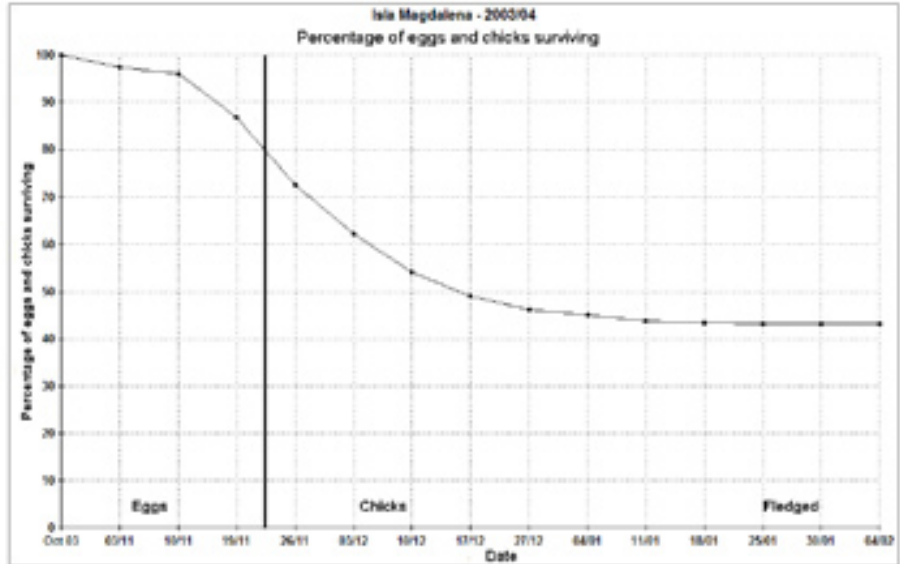

Fig. 15. Percentage of eggs and chicks surviving, Isla Magdalena 2003/04 Data source: (C) Mike Bingham, Organization for the Conservation of Penguins, 2004 


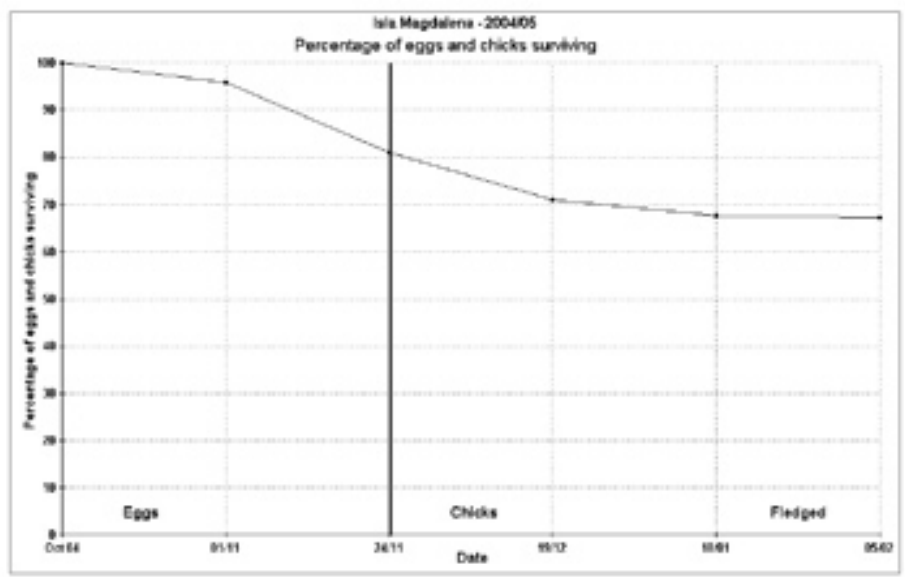

Fig. 16. Percentage of eggs and chicks surviving, Isla Magdalena 2004/05 Data source: (C) Mike Bingham, Organization for the Conservation of Penguins, 2005

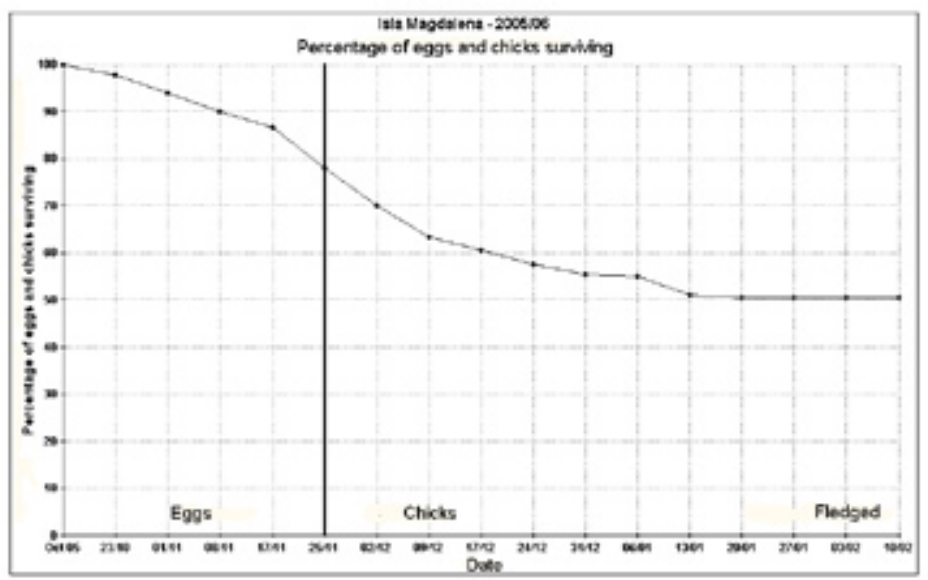

Fig. 17. Percentage of eggs and chicks surviving, Isla Magdalena 2005/06 Data source: (C) Mike Bingham, Organization for the Conservation of Penguins, 2006

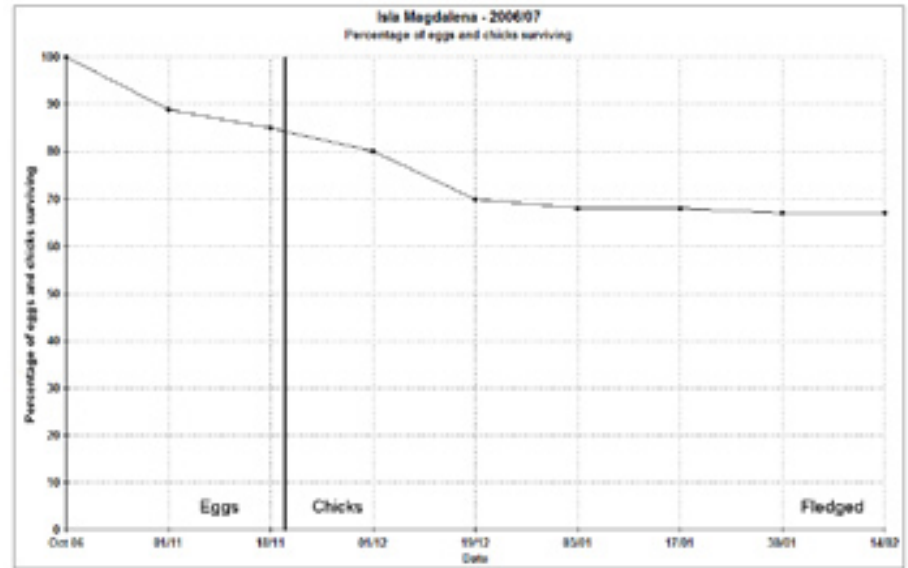

Fig. 18. Percentage of eggs and chicks surviving, Isla Magdalena 2006/07 Data source: (C) Mike Bingham, Organization for the Conservation of Penguins, 2007 


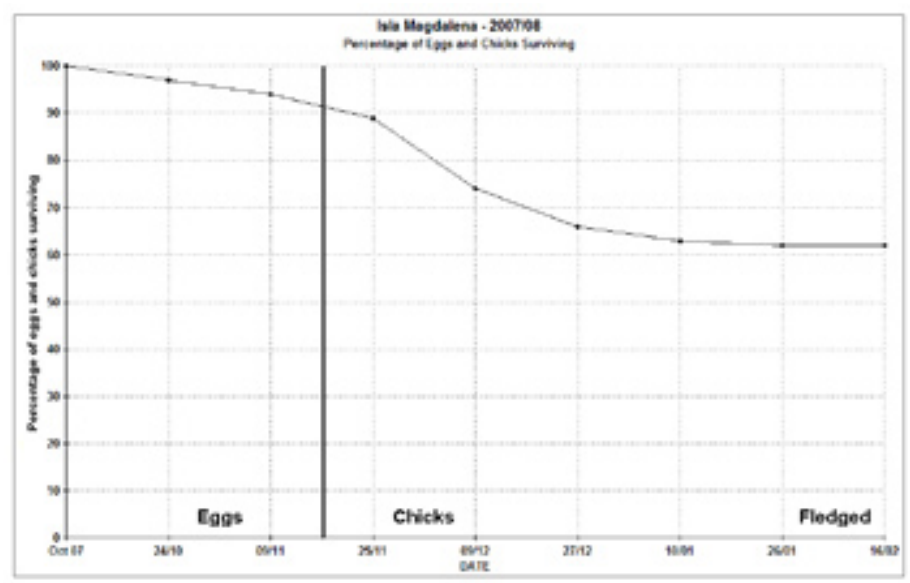

Fig. 19. Percentage of eggs and chicks surviving, Isla Magdalena 2007/08 Data source: (C) Mike Bingham, Organization for the Conservation of Penguins, 2008

blew the loose earth across the island day after day, and by December 2002, most of the penguin's nests had been abandoned as a result of eggs and small chicks being buried in these dust storms. Fortunately 2002-03 was a fairly wet season, and by 2003-04 much of the vegetation had returned. However this incident does show just how fragile the penguins are to any climate change that reduced rainfall on Magdalena.

Comparison of breeding success of nests in burrows and nests out in the open revealed surprising results. Most penguins on Magdalena Island nest in burrows, but a few penguins lay their eggs out in the open without the protection of any burrow. Most of these open nests become abandoned, suggesting that they are much less successful than nests in burrows, but that was not the case. Most open nests survive during the egg incubation period, and whilst the chicks are small and well protected by the parent, only to become abandoned when the chicks are left alone by both parents. However these nests mostly become abandoned not through the chicks being taken by predators, as had been assumed, but by the chicks leaving their open nest in search of a neighbouring unoccupied burrow.

During 2001/02 breeding success for nests in burrows was 1.38 chicks per nest, and 1.06 chicks per nest for open nests, even though virtually all open nests had been abandoned (Table 1). This was largely the result of chicks seeking out the protection of nearby vacant burrows, rather than actual chick loss. Whether open nests are less experienced pairs, pairs that arrived late, or simply pairs that are cheating the system, is unclear. However only a small proportion of the colony can make use of this system, since they rely on occupying burrows built and subsequently abandoned by other penguins in order to avoid loosing their chicks.

Annual counts of juveniles on the island conducted between 2000/01 and 2006/07 show that only a small proportion of Magdalena's juveniles return to the island prior to reaching maturity. Annual counts average around 3,000 juveniles per year, which is considerably fewer than would be required to maintain a stable population. Assuming a population of 60,000 breeding pairs, an active breeding duration of 15 years (aged 5 to 20 years), and a juvenile phase of only 3 years duration, a total of 24,000 juveniles would be expected on the island each year in order to provide a stable population. Since the population on Magdalena Island is actually increasing in size, the total number of juveniles surviving must be even greater, and yet the number actually counted on the island is very much less. Therefore it must be concluded that the great majority of surviving juveniles do not return to Magdalena until they reach maturity and begin breeding.

\section{CONCLUSIONS}

Annual monitoring shows that penguin populations on Magdalena Island are healthy and increasing, and that Contramaestre Island is being 
colonised by penguins spilling over from Magdalena Island. Breeding success is high, egg and chick losses are low, and chicks are healthy and very well fed, suggesting high juvenile survival after leaving the nest.

Tourism appears to be having no negative effect on penguins at the present level, penguins breeding in the tourist areas are accustomed to people walking among their nests, and tourist visitation did not decrease breeding success. Penguins breeding in the tourist area show a significantly weaker behavioural response to approach than penguins breeding in undisturbed areas. Tourism seems to be compatible with penguin reproduction provided that tourists remain within a set path. Given the rising number of tourists visiting the colony, careful management of tourist areas in the penguin colony on Magdalena Island must continue, allowing the development of tourism whilst protecting the Magellanic penguin colony. Further data are needed to continue evaluating the effects of tourist visitation. Tourism may possibly be having a slightly negative effect on skuas.

Oil spills from passing maritime traffic through the Straits of Magellan, and the Cabo Negro facility, is a constant threat that could seriously damage the colony at any time in the future without warning.

There is also strong evidence that if annual rainfall were to become reduced on Magdalena Island, as a result of climate change, that it is likely to have a serious effect on the penguins on Magdalena Island.

\section{ACKNOWLEDGMENTS}

Our special thanks go to the Chilean National Forestry Corporation (CONAF) and the rangers of Magdalena Island (Domingo, Floridor, Louis, Neftali, Roberto, Luis) for their continuous help. We are very thankful to the crews of "Melinka", "Fueguino",
"Don Jorge", "Hundy", "Mandamiento" and "Solo Expediciones" for their logistical support. Mike Bingham would like to thank his research assistants Nidia Mendez, Elena Mejias, Cici Legoe, Christopher Burney, Jennifer Rock, Jon Philipsborne and Joseph Brandt . Financial support was kindly provided by the Darwin Initiative (British Government), ENAP, and the Canada Research Chair in Ethnoecology and Biodiversity Conservation.

\section{LITERATURE CITED}

Bingham, M. 1998. Penguins of South America and the Falkland Islands. Penguin Conservation 11(1): 8-15.

Bingham, M. \& E. Mejias 1999. Penguins of the Magellan Region. Scientia Marina Vol:63, Supl. 1: 485-493

Bingham, M. 2002. The decline of Falklands penguins in the presence of a commercial fishing industry. Revista Chilena de Historia Natural 75: 805-818

Cevasco, C., E. Frere \& P. A. Gandini 2001. Intensidad de visitas como condicionante de la respuesta del pingüino de Magallanes (Spheniscus magellanicus) al disturbio humano. Ornitologia Neotropical 12:75-81

Gandini P., E. Frere \& D. Boersma 1998. Status and conservation of Magellanic Penguins in Patagonia, Argentina. Bird Conservation International.

van Heezik Y., \& P.J. Seddon 1990. Effect on human disturbance on the breeding behaviour of Jackass Penguins. South African Journal of Wildlife Research 20: 89-93

Yorio P. \& D. Boersma 1992. The effects of human disturbance on Magellanic Penguin Spheniscus magellanicus beahaviour and breeding success. Bird Conservation International 2:161-173 